\section{Potential yield of soybean promising lines in acid soil of central Lampung, Indonesia}

\author{
Heru Kuswantoro \\ Indonesian Legume and Tuber Crops \\ Research Institute, Indonesian Agency for \\ Agricultural Research and Development, \\ Malang, Indonesia
}

\section{Abstract}

Most of Indonesia dryland is covered by acid soil which lead to the decreasing potential yield of the crops. In different areas soybean potential yield also different depends on the different soil $\mathrm{pH}$ and the availability of the soil. The objective of the research was to study the potential yield of soybean promising lines in acid soil of Central Lampung, Indonesia. Ten promising lines and two check varieties (Tanggamus and Wilis) were grown in acid soil with $\mathrm{pH}$ 4.7. The results showed that the highest seed yield was showed by SC5P2P3.5.4.1-5 with 2.51 t/ha. Other soybean promising lines with seed yield over than 2 $\mathrm{t}^{-1} \mathrm{~h}^{-1}$ was SJ-5/Msr.99.5.4.5-1-6-1 and the check variety Tanggamus. The highest yield of SC5P2P3.5.4.1-5 was caused by the high number of filled pods and the large of seed size. Other nine promising lines also can be developed to obtained grain yield as many as Tanggamus yield in the area with similar soil and climate conditions.

\section{Introduction}

Approximately $30-40 \%$ of the world total land area is covered by acid soil. ${ }^{1}$ Indonesia also has acid soil problem, where most of the dryland $(69 \%)$ is covered by acid soil. ${ }^{2}$ Central Lampung is one of the Indonesian regencies in Province of Lampung that experiences acid soil on the most area. There are many problems found in this soils, that can be divided into macronutrient deficiencies and micronutrient toxicities. Mineral nutrients deficiencies occur on calcium, magnesium, molybdenum, and phosphorus; while micronutrient toxicities occur on aluminum and manganese. ${ }^{3,4}$ Therefore, acid soil can limit crop growth potential. ${ }^{5}$ For improving crops production, minerals toxicity can be ameliorated by surface application of lime. But this lime application usually only for short term period and the soil properties will be back to the previous acidic soil condition. An alternative strategy can be provided for increasing crops production on acid soils by improving genetic $\mathrm{Al}^{3+}$ resistance. The use of stable genotypes for high grain yield is very important. ${ }^{6}$ However, under diverse agro-ecological conditions, phenotypic performance of a genotype is not similar. ${ }^{7}$ It is because genotypic expression of a phenotype is environmentally dependent, where the gene expression is subject to modification by the environment. ${ }^{8}$ High yield capacity and favorable weather conditions may contribute to the high yield. ${ }^{9}$ It suggests that ecophysiological parameters are very important in selecting good varieties, ${ }^{10}$ as well as the genetic ones. In a specific area, a crop has similar performances when the environmental factors, such as rain fall, humidity, solar intensity and temperature, is similar. This is because soil condition is relatively similar for a long period, since in the agricultural land the soil condition is usually maintained similar by adding fertilizers. In this scheme, generally specific adapted variety has higher performance than national superior variety. Therefore, specific adapted variety is suggested to be grown in this specific area. This study was aimed to find out potential yield of soybean promising lines in acid soil of Central Lampung Province.

\section{Materials and Methods}

The materials consisted of 10 promising lines (SC2P2.99.5.4.5-1-6-1, SC2P2.151.3.5.110, SC5P2P3.5.4.1-5, SC5P2P3.23.4.1-3-28-3, SC5P2P3.23.4.1-5, SC5P2P3.48.31.1-10, SJ5/Msr.99.5.4.5-1-6-1， Msr/SJ-5.21.3.7-3-27-1, Msr/SJ-5.23.4.1-3-28-3 and Msr/SJ-5.23.4.1-5) and two check varieties (Tanggamus and Wilis). The study was conducted in Central Lampung from November 2009 to February 2010. The soil pH was 4.7, which is classified as very strong acid according to the USDA; ${ }^{11}$ soil properties are shown in Table 1.

The rainfall was about $250-350 \mathrm{~mm}$, with temperature of $25-32^{\circ} \mathrm{C}$. The experimental design was a randomized completely blocks design with 4 replications. Plot size was $2.8 \times 4.5 \mathrm{~m}$, a spacing of $40 \times 15 \mathrm{~cm}, 2$ plants per hill. Fertilization was applied with $33.75 \mathrm{Kg} \mathrm{N}$, $45 \mathrm{Kg} \mathrm{P}_{2} \mathrm{O}_{5}, 37.5 \mathrm{Kg} \mathrm{K} \mathrm{K}_{2} \mathrm{O}$ per ha, which spread before planting. Soil tillage was applied to obtain optimal soil structure condition for ideal growth of the soybean. Drainage canals were done before planting and herbicides applied. Control of weeds, pests and diseases were performed optimally. Observations were carried out on 10 randomly selected plants from each genotype in all of the 4 replications for number of branches per plant, number of reproductive nodes per plant, number of filled pods and unfilled pods per plant, $50 \%$ flowering age, $95 \%$ maturity age, 100 grains weight and grain yield. Flowering age was determined when the $50 \%$ plants in a plot were flowering.
Correspondence: Heru Kuswantoro, Indonesian Legume and Tuber Crops Research Institute, Jl. Raya Kendalpayak km 8, P0 Box 66, Malang, East Java 65101, Indonesia.

Tel.: +62.0341.801.4682.

E-mail: herukusw@yahoo.com

Key words: acid soil, potential yield, soybean.

Conflict of interests: the author declares no potential conflict of interests.

Received for publication: 21 July 2014.

Revision received: 18 August 2014.

Accepted for publication: 18 August 2014.

This work is licensed under a Creative Commons Attribution NonCommercial 3.0 License (CC BYNC 3.0).

CCopyright H. Kuswantoro, 2014

Licensee PAGEPress srl, Italy

International Journal of Plant Biology 2014; 5:5566 doi:10.4081/pb.2014.5566

Analysis of variance was applied for data analyzing and continued with least significant difference (LSD) for mean comparison.

\section{Results and Discussion}

Soybean pods appear from the main stem or from the branches of the main stem. The number of branches per plant is related to the number of pod per plant, where the number of branches per plant gives the highest positive direct effect than other soybean characters. ${ }^{12,13}$ The number of branches is one of the agronomic traits that had highly positive correlation on grain yield per plant and positive direct effect on grain yield per plant in soybean. ${ }^{13,14}$ Therefore, the number of branches can affect the number of pods and grain yield. The results of this study showed that the highest number of branches per plant was achieved by Tanggamus, followed by Wilis (Table 2 ). Both of these varieties were check varieties which were used as a measure of adaptation in acid soil; this suggests that based on the number of branches, the check varieties are effective to measure the adaptation of soybean lines. However, the measurement of the soybean adaptation in acid soil is not only based on number of branches but also on other characters, especially grain yield.

The reproductive nodes are the nodes on soybeans plant that have pods. Egli et al. ${ }^{15}$ stated that the nodes on the main stem and on the branches reached a maximum at R5. The highest number of reproductive nodes was shown by Tanggamus followed by SC2P2.99.5.4.5-1-61 and Wilis (Table 2). A study by Carpenter and 
Board suggested a close relationship between the number of branches and the number of reproductive nodes, ${ }^{6}$ where greater branch dry matter per plant created more branch nodes, branch reproductive nodes, and branch pods. Reproductive nodes lay in the branch of the plant.

In this study, Tanggamus and Wilis, which had the highest number of reproductive nodes, also had the highest number of branches. The number of reproductive nodes will affect pod number. As a result, pods per reproductive branch node will also affect grain yield. ${ }^{6}$

The highest number of filled pods per plant was achieved by Tanggamus. Statistically, there are three lines that had a number of filled pods equivalent to Tanggamus, i.e. SJ5/Msr.99.5.4.5-1-6-1, SC2P2.99.5.4.5 and SC5P2P3.5.4.1-5-1-6-1 (Table 3). The highest number of unfilled pods was reached by SJ5/Msr.99.5.4.5-1-6-1. The number of filled pods in this study was lower than the number of filled pods in another study (with the same materials). ${ }^{16}$ This occurred because the soil $\mathrm{pH}$ in this study was lower ( $\mathrm{pH} 4.70)$ than soil $\mathrm{pH}$ (4.89) in the other one. ${ }^{16}$ If compared to lower $\mathrm{pH}$ studies with less irrigation conditions, ${ }^{17}$ this study shows higher number of filled pods. However, when it is compared to lower $\mathrm{pH}$ studies with sufficient irrigation conditions, ${ }^{17}$ the number of filled pods in this study is lower. Deleterious effect of low $\mathrm{pH}$ and low nutrient supply lead acid soil to suppress the number of filled pods. ${ }^{18,19}$ In addition, water deficit might induce pod abortion during pod development, ${ }^{20}$ leading to a decreasing number of filled pods.

With the relatively high number of filled and unfilled pods, SJ-5/Msr.99.5.4.5-1-6-1 line had the higher number of total pods with respect to the other lines. Unfilled pods are the ones that have no seed because the seed formation is hampered due to the unfavorable environmental conditions. Therefore, in a better environmental condition, SJ-5/Msr.99.5.4.5-1-6-1 may achieve higher yield because the pods filling may proceed perfectly and the unfilled pods would have became filled pods. However, the number of unfilled pods can also be higher if the genetic factor is more influential. The variability of unfilled pods number was due to the genetic constitution, which suggested that genetic factors had higher effect than environment, as stated by Sahay et al. ${ }^{21}$ since broadsense heritability of unfilled pods was high (93.1\%).

In general, the flowering ages of tested genotypes were almost the same, which were between 38-40 days. This result does not differ when compared to other studies conducted in optimal conditions, but it is different if compared to drought condition. ${ }^{17}$ Differences occurred at the maturity age ranging from 82 87 days. The earliest maturity age shown by Wilis while the longest maturity age shown by
Table 1. Soil properties of Restu Baru village, Rumbia Regency, Central Lampung, Indonesia.

\begin{tabular}{lcc} 
Soil properties & Value & Criteria \\
$\mathrm{pH}\left(\mathrm{H}_{2} \mathrm{O}\right)$ & 4.70 & Very strong acid* $^{*}$ \\
$\mathrm{C}_{\text {organic }}(\%)$ & 2.01 & Medium $^{\circ}$ \\
\hline $\mathrm{N}(\%)$ & 0.066 & Very low $^{\circ}$ \\
$\mathrm{P}_{2} \mathrm{O}_{5} \mathrm{BI}(\mathrm{ppm})$ & 1.30 & Very low $^{\circ}$ \\
\hline $\mathrm{K}\left(\mathrm{me} .100 \mathrm{~g}^{-1}\right)$ & 0.42 & Medium $^{\circ}$ \\
$\mathrm{Ca}\left(\mathrm{me} .100 \mathrm{~g}^{-1}\right)$ & 3.24 & Low $^{\circ}$ \\
\hline $\mathrm{Mg}\left(\mathrm{me} .100 \mathrm{~g}^{-1}\right)$ & 0.64 & Low $^{\circ}$ \\
$\mathrm{CEC}\left(\mathrm{me}^{-1} 100 \mathrm{~g} \mathrm{~g}^{-1}\right)$ & 7.22 & Low $^{\circ}$ \\
\hline
\end{tabular}

According to *USDA and ${ }^{\circ}$ Soepraptohardjo. ${ }^{11,12}$

Table 2. Number of branches per plant, and number of reproductive nodes per plant of acid-adaptive soybean promising lines in Central Lampung, Indonesia.

\begin{tabular}{lcc} 
Genotype & Branches per plant & Reproductive nodes per plant \\
SC2P2.99.5.4.5-1-6-1 & $9.0^{\mathrm{bc}}$ & $29.5^{\mathrm{b}}$ \\
SC5P2P3.23.4.1-3-28-3 & $8.3^{\mathrm{c}}$ & $24.5^{\mathrm{ce}} \mathrm{e}$ \\
\hline SC2P2.151.3.5.1-10 & $9.0^{\mathrm{bc}}$ & $23.8^{\mathrm{ce}} \mathrm{e}$ \\
SC5P2P3.5.4.1-5 & $8.3^{\mathrm{c}}$ & $23.8^{\mathrm{ce}} \mathrm{e}$ \\
\hline SC5P2P3.23.4.1-5 & $8.5^{\mathrm{bc}}$ & $19.8^{\mathrm{e}}$ \\
SC5P2P3.48.31.1-10 & $8.8^{\mathrm{bc}}$ & $23.8^{\mathrm{ce}} \mathrm{e}$ \\
\hline SJ-5/Msr.99.5.4.5-1-6-1 & $9.8^{\mathrm{bc}}$ & $24.8^{\mathrm{bce}}$ \\
Msr/SJ-5.21.3.7-3-27-1 & $8.3^{\mathrm{c}}$ & $23.3^{\mathrm{ce}} \mathrm{e}$ \\
\hline Msr/SJ-5.23.4.1-3-28-3 & $8.3^{\mathrm{c}}$ & $22.5^{\mathrm{e}} \mathrm{e}$ \\
Msr/SJ-5.23.4.1-5 & $8.3^{\mathrm{c}}$ & $24.0^{\mathrm{ce}} \mathrm{e}$ \\
\hline Wilis & $10.3^{\mathrm{b}}$ & $27.5^{\mathrm{bc}}$ \\
Tanggamus & $12.3^{\mathrm{a}}$ & $34.8^{\mathrm{a}}$ \\
\hline LSD 5\% & $1.8^{\mathrm{a}}$ & 4.94
\end{tabular}

Value in the same column ane followee by the same letter was not significantly different at LSD 5\%.

Table 3. Number of filled pods per plant and number of unfilled pods per plant of acidadaptive soybean promising lines in Central Lampung, Indonesia.

\begin{tabular}{lcc} 
Genotype & Filled pods per plant & Unfilled pods per plant \\
SC2P2.99.5.4.5-1-6-1 & $69.8^{\text {abc }}$ & $7.5^{\text {bcd }}$ \\
SC5P2P3.23.4.1-3-28-3 & $63.3^{\text {bcd }}$ & $6.8^{\text {cd }}$ \\
\hline SC2P2.151.3.5.1-10 & $65.0^{\text {bcd }}$ & $9.5^{\mathrm{b}}$ \\
SC5P2P3.5.4.1-5 & $73.3^{\text {ab }}$ & $7.0^{\text {cd }}$ \\
\hline SC5P2P3.23.4.1-5 & $51.0 \mathrm{e}$ & $8.3^{\text {bc }}$ \\
SC5P2P3.48.31.1-10 & $65.5^{\text {bcd }}$ & $6.0^{\text {cd }}$ \\
\hline SJ-5/Msr.99.5.4.5-1-6-1 & $74.3^{\text {ab }}$ & $13.8^{\text {a }}$ \\
Msr/SJ-5.21.3.7-3-27-1 & $57.8^{\text {cd }} \mathrm{e}$ & $5.8^{\mathrm{d}}$ \\
\hline Msr/SJ-5.23.4.1-3-28-3 & $54.5^{\mathrm{d}} \mathrm{e}$ & $5.5^{\mathrm{d}}$ \\
Msr/SJ-5.23.4.1-5 & $58.3^{\mathrm{cd}} \mathrm{e}$ & $6.3^{\mathrm{cd}}$ \\
\hline Wilis & $65.3^{\mathrm{bcd}}$ & $7.3^{\mathrm{bcd}}$ \\
Tanggamus & $82.3^{\mathrm{a}}$ & $7.5^{\mathrm{bcd}}$ \\
\hline LSD 5\% & 13.89 & 2.42
\end{tabular}

Value in the same column and followed by the same letter was not significantly different at LSD 5\% 
Tanggamus (Table 4). The longest duration of pod filling period was shown by Tanggamus, that in this study had the earliest flowering age but the longest maturity age (49 days), while the shortest seed filling period was reached by Wilis (43 days). Usually, the longer generative phase varieties will produce higher grain yield. ${ }^{13}$

Grain size is expressed in weight of 100 grains. Largest grain size was indicated by SC5P2P3.48.31.1-10 lines that reached 14.22 g/100 grains (Table 4). In general, the ten tested lines had a larger grain size than both check varieties. Tanggamus was the genotype that had the smallest grain size. In this study, Tanggamus and Wilis showed smaller seed size than in the description, ${ }^{22}$ suggesting that the two checks varieties showed grain size decreasing. All promising lines showed grain sizes higher than Wilis and Tanggamus, where there was one promising lines with seed size more than $14 \mathrm{~g} / 100$ grains i.e. SC5P2P3.48.31.1-10 (Table 4). The magnitude of grain size depends on grains filling rate, ${ }^{23}$ but in this study Tanggamus varieties with the longest pod filling duration resulted the lowest weight of 100 grains. It is because photosynthate of Tanggamus was used for grains formation lead more number of grains, but smaller grain weight or grain size due to the photosynthate was partitioned on many grains.

The highest grain yield was shown by SC5P2P3.5.4.1-5 with 2.51 t.ha $^{-1}$. Another line having grain yield more than 2 t.ha $^{-1}$ was SJ-

Table 4. Flowering age and maturity age of acid-adaptive soybean promising lines in Central Lampung, Indonesia.

\begin{tabular}{lcc} 
Genotype & Flowering age (days) & Maturity age (days) \\
SC2P2.99.5.4.5-1-6-1 & $39.5^{\mathrm{bc}}$ & $85.8^{\mathrm{b}}$ \\
SC5P2P3.23.4.1-3-28-3 & $38.3 \mathrm{e}$ & $84.0^{\mathrm{cd}}$ \\
\hline SC2P2.151.3.5.1-10 & $38.5^{\mathrm{d}} \mathrm{e}$ & $83.8^{\mathrm{d}}$ \\
SC5P2P3.5.4.1-5 & $39.8^{\mathrm{ab}}$ & $84.0^{\text {cd }}$ \\
\hline SC5P2P3.23.4.1-5 & $39.8^{\mathrm{ab}}$ & $84.3^{\mathrm{c}}$ \\
SC5P2P3.48.31.1-10 & $38.8^{\mathrm{de}}$ & $83.0^{\mathrm{e}}$ \\
\hline SJ-5/Msr.99.5.4.5-1-6-1 & $40.0^{\mathrm{ab}}$ & $85.8^{\mathrm{b}}$ \\
Msr/SJ-5.21.3.7-3-27-1 & $38.8^{\mathrm{de}}$ & $84.0^{\mathrm{cd}}$ \\
\hline Msr/SJ-5.23.4.1-3-28-3 & $38.5^{\mathrm{de}}$ & $84.0^{\mathrm{cd}}$ \\
Msr/SJ-5.23.4.1-5 & $40.3^{\mathrm{a}}$ & $85.0^{\mathrm{bc}}$ \\
\hline Wilis & $39.0^{\mathrm{cd}}$ & $82.0 \mathrm{f}$ \\
Tanggamus & $38.3^{\mathrm{e}}$ & $86.8^{\mathrm{a}}$ \\
\hline LSD 5\% & 0.67 & 0.47
\end{tabular}

Value in the same column and followed by the same letter was not significantly different at LSD 5\%

\section{Conclusions}

The highest grain yield was shown by SC5P2P3.5.4.1-5 with 2.51 t/ha, followed by SJ5/Msr.99.5.4.5-1-6-1 with 2.03 t/ha. SC5P2P3.5.4.1-5 had the highest grain yield because it had a lot of pods and a relatively large grain size than the other lines. SJ5/Msr.99.5.4.5-1-6-1 can be also developed in some areas that have similar soil and climate conditions. The number of filled pods affects more grain yield than other observed characters. Since Tanggamus and the other nine promising lines were statistically not different, all of the nine promising lines can be developed to obtained as many grain yield as Tanggamus.

\section{References}

Table 5. Grain size (100 grains weight) and grain yield of acid-adaptive soybean promising lines in Central Lampung, Indonesia.

\begin{tabular}{lcc} 
Genotype & 100 grain weight $(\mathrm{g})$ & Grain yield (t.ha-1) \\
SC2P2.99.5.4.5-1-6-1 & $13.50^{\mathrm{ab}}$ & $1.84^{\mathrm{b}}$ \\
SC5P2P3.23.4.1-3-28-3 & $13.53^{\mathrm{ab}}$ & $1.89^{\mathrm{b}}$ \\
\hline SC2P2.151.3.5.1-10 & $12.59^{\mathrm{abc}}$ & $1.86^{\mathrm{b}}$ \\
SC5P2P3.5.4.1-5 & $13.76^{\mathrm{ab}}$ & $2.51^{\mathrm{a}}$ \\
\hline SC5P2P3.23.4.1-5 & $13.18^{\mathrm{ab}}$ & $1.88^{\mathrm{b}}$ \\
SC5P2P3.48.31.1-10 & $14.22^{\mathrm{a}}$ & $1.86^{\mathrm{b}}$ \\
\hline SJ-5/Msr.99.5.4.5-1-6-1 & $13.63^{\mathrm{ab}}$ & $2.03^{\mathrm{b}}$ \\
Msr/SJ-5.21.3.7-3-27-1 & $12.94^{\mathrm{ab}}$ & $1.77^{\mathrm{b}}$ \\
\hline Msr/SJ-5.23.4.1-3-28-3 & $12.57^{\mathrm{abc}}$ & $1.77^{\mathrm{b}}$ \\
Msr/SJ-5.23.4.1-5 & $13.78^{\mathrm{a}}$ & $1.78^{\mathrm{b}}$ \\
\hline Wilis & $11.59^{\mathrm{bc}}$ & $1.97^{\mathrm{b}}$ \\
Tanggamus & $10.52^{\mathrm{c}}$ & $2.04^{\mathrm{b}}$ \\
\hline LSD 5\% & 2.17 & 0.41 \\
\hline
\end{tabular}

Value in the same column and followed by the same letter was not significantly different at LSD 5\%

1. Uexkull von HR, Mutert E. Global extent, development and economic impact of acid soils. In: Date RA, Grundon NJ, Raymet GE, Probert ME, (eds). Plant-soil interactions at low $\mathrm{pH}$ : principles and management. Dordrecht: Kluwer Academic Publishers; 1995. pp 5-9.

2. Mulyani A. Potency of acid soil for developing agriculture. Warta Penelitian dan Pengembangan Pertanian 2006;28:16-17. [Article in Indonesian].

3. Horst WJ. Fitting maize into sustainable cropping systems on acid soil of the tropics. In: Management and conservation of tropical acid soils for sustainable crop production. Proceeding of a consultants meeting. Vienna 1-3 March 1999. Joint FAO/IAEA Divisions of Nuclear Techniques 
in Food and Agriculture. 2000. pp 47-59.

4. Thomas RJ, Ayarza M, Lopes AS. Management and conservation of acid soils in the savannahs of Latin America: lessons from the agricultural development of the Brazilian cerrados. In: Management and conservation of tropical acid soils for sustainable crop production. Proceeding of a consultants meeting. Vienna 1-3 March 1999. Joint FAO/IAEA Divisions of Nuclear Techniques in Food and Agriculture. 2000. pp 5-28.

5. Phengsouvana V, Attanandana T, Yost RS. Lime application to two acidic upland soils for soybean production in Champasak Province, Lao PDR. Kasetsart J (Nat. Sci.) 2009;43:19-27.

6. Carpenter AC, Board JE. Branch yield components controlling soybean yield stability across plant populations. Crop Sci 1997;37:885-91.

7. Ali N, Javidfar F, Mirza Y. Selection of stable rapeseed (Brassica napus L.) genotypes through regression analysis. Pakistan J Bot 2003;35:175-83.

8. Kang MS. Using genotype-by-environment interaction for crop cultivar development. Adv Agron 1998;35:199-240.

9. Andric L, Rastija M, Teklic T, Kovacevic V. Response of maize and soybeans to liming. Turk J Agric For 2012;36:415-20.

10. Zhu GJ, Jiang GM, Hao NB, et al. Relationship between ecophysiologycal fetures and grain yields in different soybean varieties. Acta Botanica Sinica 2002;44:725-30.

11. USDA. Natural resources conservation service soils. Soil survey manual. Chapter three. Available from: http://www.nrcs.usda.gov/wps/portal/nrcs/d etail/soils/ref/?cid=nrcs142p2_054253

12. Soepraptohardjo M. Survey of soil capability. Bogor: Soil Research Center Institute; 1983. [Book in Indonesian].

13. Machikowa T, Laosuwan P. Path coefficient analysis for yield of early maturing soybean. Songklanakarin J Sci Technol 2011;33:365-8.

14. Wirnas D, Widodo I, Trikoesoemaningtyas S, Sopandie D. Selection of agronomic characters for developing index selection on $\mathrm{F} 6$ generation of 11 soybean population. Bull Agron 2006;34:19-24. [Article in Indonesian].

15. Egli DB, Guffy RD, Leggett JE. Partitioning of assimilate between vegetative and reproductive growth in soybean. Agron J 1985:77:917-22.

16. Rauf AW. Multilocation trials of 5-6 rice and soybean promising lines with productivity $>20 \%$ of existing condition in West Papua Province. Research Report. Available

from: http://km.ristek.go.id/assets/files/KEMTAN/761\%20D/761.pdf

17. Kuswantoro H, Zen S. Performance of acid-tolerant soybean promising lines in two planting seasons. Int J Biol 2013;5:4956 .

18. Uguru MI, Oyiga BC, Jandong EA. Responses of some soybean genotypes to different soil $\mathrm{pH}$ regimes in two planting seasons. Afr J Plant Sci Biotechnol 2012;6:26-37.

19. Board JE, Caldwell AG. Response of determinate soybean cultivars to low $\mathrm{pH}$ soils.
Plant Soil 1991;132:289-92.

20. Liu F. Physiological regulation of pod set in soybean (Glycine max L. Merr.) during drought at early reproductive stages. Thesis Dissertation. Department of Agricultural Sciences; The Royal Veterinary and Agricultural University; Copenhagen; 2014.

21. Sahay G, Sarma BK, Durai AA. Genetic variability and interrelationship in $\mathrm{f} 2 \mathrm{seg}$ regating generation of soybean \{Glycine $\max (\mathrm{L})$ Merril \} in mid-altitude of Meghalaya. Agric Sci Digest 2005;25:10710.

22. Indonesian Legume and Tuber Crops Research Institute. Description of superior varieties of legume and tuber crops. Malang: Indonesian Legume and Tuber Crops Research Institute; 2009. p 175. [Article in Indonesian].

23. Harmida. Growth response of promising lines of soybean (Glycine max (L.) Merrill) in acidic soil. Jurnal Penelitian Sains 2010;13:13209-48. [Article in Indonesian].

24. Malik MFA, Ashraf M, Qureshi AS, Khan MR. Investigation and comparison of some morphological traits of the soybean populations using cluster analysis. Pakistan J Bot 2011;43:1249-55.

25. Arshad M, Ali N, Ghafoor A. Character correlation and path coefficient in soybean Glycine max (L.) Merrill. Pakistan J Bot 2006;38:121-30.

26. El-Badawy MEM, Mehasen SAS. Correlation and path coefficient analysis for yield and yield components of soybean genotypes under different planting density. Asian J Crop Sci 2012:4:150-8. 